\title{
Unemployment Insurance and Wages
}

\author{
by Stephen Nickell*
}

As Professor Malinvaud makes clear in his excellent survey of the consequences of the unemployment insurance system, one of the key issues concerns the impact of the system on the level of unemployment. Clearly if the unemployment insurance system is made more generous as regards either the level of benefits paid out or the way the system is operated, then we would expect this to lead to an increase in unemployment. The mechanism by which this comes about is of some interest. The standard moral hazard argument set out in Professor Malinvaud's paper is, in fact, only the first part of the story. The unemployed state becomes more desirable and workers will, therefore, enter it more readily and remain in it for longer periods. This is essentially a supply side phenomenon and it is this part of the story which has been the subject of extensive empirical analysis which is noted in Professor Malinvaud's paper. An interesting question, however, is the ultimate consequence of these supply side effects for the level of unemployment. This is a general equilibrium problem which requires us to specify the remainder of the economy.

The problem is highlighted by the following argument taken from the Atkinson [1981] survey article. Suppose a rise in benefits leads to some workers searching less intensively, being more choosy about which job vacancies they will accept. These unfilled vacancies will now be available for other workers and they may well obtain work more quickly than they would otherwise have done. As a consequence, the aggregate impact of the rise in benefits is not at all clear cut. It is this kind of argument which forces one to look at the general equilibrium implications of the insurance system in order to determine its full consequences.

If unemployment is to rise as a result of more generous benefit levels, then employment must fall. In order for this to come about, real wages must rise and it is the mechanism which brings this about which is of interest. For those who assert that the real wage adjusts to bring about the equality of supply and demand in the labour market, there is no difficulty. The rise in benefits reduces supply, raises the real wage and reduces employment. The consequences for unemployment depend simply on the size of the supply response and the wage elasticities of supply and demand. Many, including the present author, find this view of the operation of the labour market somewhat unappealing since it does not appear to accord with the evidence. What, then, is the mechanism at work if we take some other view of the labour market. In what follows, I shall discuss two

\footnotetext{
* Professor, London School of Economics.
} 
models of wage determination which give some idea as to how the unemployment insurance system influences the labour market when wages are not competitively determined.

The first model is one in which firms set wages and belongs to a set of models which are typically referred to as "efficiency wage models" (see, for example, Stiglitz [1984], Yellen [1984] or Johnson and Layard [1983]). Suppose that quitting on the part of workers generates real resource costs for the firm. Suppose further that the quit rate depends on the real wage paid by the firm $w$, relative to the real income which a quitting worker can expect. For simplicity we can represent the expected alternative income as $w^{*}(1-u)+b u$ where $w^{*}$ is the expected real wage in the rest of the economy, $u$ is the unemployment rate and $b$ is the level of real benefit. So the quit rate $q$ can be written

$$
q=q\left(\frac{w}{w^{*}(1-u)+b u}\right), \quad q^{\prime}<0, \quad q^{\prime \prime}>0 .
$$

If the economy consists of $n$ identical firms, then we can write the real profits of a representative firm as

$$
\pi=F(N / n, K / n)-(w+\Phi q) N / n
$$

where $F$ is the production function, $N, K$ are aggregate employment and capital stock and $\Phi$ is the real cost of a quit. With $K$ as given, we can generate the first order conditions and set $w=w^{*}$ for long run equilibrium. Taking $L$ as the (fixed) labour force and defining $\rho=b / w$ (the replacement ratio) gives us

$$
\begin{aligned}
& F_{1}(L(1-u) / n, K)-w-\Phi q\left\{((1-u)+u \rho)^{-1}\right\}=0 \\
& w+\Phi q^{\prime}\left\{((1-u)+u \rho)^{-1}\right\}((1-u)+u \rho)^{-1}=0 .
\end{aligned}
$$

These equations determine long run equilibrium values of unemployment, $u$, and the real wage, $w$. It is easy to check that if benefits rise then $u$ will rise. The mechanism here is simply that when $\rho$ increases, excessive quitting is encouraged. In order to try and counteract this, each individual firm raises wages and unemployment increases. In the new equilibrium it is, in fact, the unemployment increase which serves to offset the increased quitting since relative wages cannot change. There are, of course, many more complicated variants of this model but they typically exhibit this kind of property.

The other model I shall consider explicitly introduces trade unions. Consider the following very simple model where the union sets the wage given the demand curve for labour (i.e. employers set employment given the wage). Suppose the union maximises a utility function of the form $u(N, w, \rho)$ where the notation is the same as before. Union utility is increasing in the replacement ratio, $\rho$, because if a union member fails to obtain a job in the firm, he is liable to enter unemployment and is better off if $\rho$ is bigger. So the union chooses $w$ to solve

$$
\max _{w} u(N(w), w, \rho)
$$

where $N(w)$ is the labour demand function. The first order condition is

$$
u_{1} N_{n}+u_{2}=0
$$

and in this case it is trivial to show that $w$ is increasing in $\rho$ and thus employment is decreasing in $\rho$. Again, the same result follows in more complex union-employer bargaining models essentially because anything which increases the "outside opportunities " of workers will lead to a higher wage and reduced employment. 
To summarise, we have made more precise just how it is that a rise in unemployment benefit will increase wages and reduce employment even in a world where wages are not set competitively. This is an important issue with regard to unemployment insurance because it is simply not enough to argue that such insurance will tend to reduce the supply of labour. What is needed is some insight into the mechanism by which this is transmitted to employment in realistic, non competitive models of the labour market and we have provided an introduction to the sort of arguments which may be pursued.

\section{REFERENCES}

ATKINSON, A. B. [1981]: "Unemployment Benefits and Incentives", in The Economics of Unemployment in Britain, ed. J. Creedy, Butterworths, London.

JOHNSON, G., and LAYARD, R. [1983] : “Long Run Unemployment and Labor Market Policy ", forthcoming in O. Ashenfelter and R. Layard (eds.) Handbook of Labor Economics, NorthHolland.

STIGLITZ, J. E. [1984]: “Theories of Wage Rigidity", paper presented at the conference on Keynes' Economic Legacy, Delaware, January 12-13.

YELLEN, J. [1984]: "Efficiency Wage Models of Unemployment", The American Economic Review, Vol. 74, No. 2 May, p. 200. 